\title{
Does Early Diabetic Kidney Damage Alter Renal Elasticity? An Ultrasound-Based, Two-Dimensional Shear Wave Elastography Study
}

\section{Erken Dönem Diyabetik Böbrek Hasarı Böbrek Elastisitesini Etkiler mi?: Ultrason Temelli 2B Shear Wave Elastografi Çalışması}

\author{
Nesrin GUNDUZ $\odot$, Aysenur BUZ $\odot$, Adnan KABAALIOGLU $\odot$
}

Ethics Committee Approval: This study was approved by Istanbul Medeniyet University Göztepe Educational and Research Hospital Ethics Committee, 27 June 2018, 2018/0255. Conflict of interest: The authors declare that they have no conflict of interest. Funding: None.

Informed Consent: Informed consents were taken from the participants of the study.
Cite as: Gunduz N, Buz A, Kabaalioglu A. Does early diabetic kidney damage alter renal elasticity? An ultrasound-based, two-dimensional shear wave elastography study. Medeni Med J. 2021;36:209-16

\begin{abstract}
Objective: Kidney damage caused by type 2 diabetes mellitus (T2DM) can reduce renal elasticity. Limited number of data exist indicating whether early kidney damage causes stiffening of renal tissue. This comparative study aims to assess kidney elasticity in T2DM patients with or without moderate albuminuria, using ultrasound-based two-dimensional shear wave velocity (2D-SWV) measurements.

Methods: Fifty-seven cases (40 T2D patients with stage 1 or 2 chronic kidney disease and 17 age- and sex-matched healthy controls) were included in this single-center prospective study. The T2DM patients were divided into those with moderate albuminuria $(n=22)$ and those without albuminuria $(n=18)$. Bilateral renal parenchymal 2D-SWV values were measured (separately) in the upper, middle, and lower kidney regions. Group data were compared using the t-test or Mann-Whitney-U test (whichever appropriate). Inter-observer agreement was assessed by deriving the intra-class correlation coefficient.

Results: There was no difference between the T2DM and control groups in terms of the median age $[55.5$ (50-62) vs. 55 (48.5-59.5) years, $p=0.48]$ and sex ratio [18 (45\%) males vs. 10 (58.8\%) females, $p=0.34]$. The average regional $2 D-S W V$ values were all similar between the groups (all $p>0.05)$. The average $2 D$-SWV values were similar between the subgroups with and without albuminuria. The inter-observer agreement was good (intra-class correlation coefficient $=0.66$, 95\% CI 0.19-0.88, $p=0.006$ ).

Conclusion: Kidney elasticity does not seem to be compromised in patients with diabetes and preserved estimated glomerular filtration rate with or without moderate albuminuria.
\end{abstract}

Keywords: Shear wave elastography, diabetes mellitus, albuminuria

ÖZ

Amaç: Tip II diyabetin neden olduğu böbrek hasarı böbrek elastisitesini bozabilir. Erken evre böbrek hasarının böbrek dokusunda sertleşmeye neden olup olmadığı konusunda sınırlı veri buIunmaktadır. Bu karșılaștırmalı calıșmada; ultrason temelli $2 B$ Shear wave hızları (2B-SWH) ile, orta derecede albüminürisi olan ve olmayan diyabetiklerin böbrek elastisitesini değerlendirmeyi amaçladık.

Yöntem: Bu tek merkezli, prospektif calıșmaya toplam 57 olgu (evre 1 veya 2 kronik böbrek hastalığı olan DM-II tanılı 40 hasta ile yas ve cinsiyet uyumlu 17 sağlıklı kontrol) dahil edildi. Tip II diyabetlilerin oluşturduğu grup kendi içinde albüminürisi olan $(n=22)$ ve albüminürisi olmayanlar $(n=18)$ olmak üzere iki alt grup olusturdu. Her iki taraf böbrek parankim 2B-SWH değerleri üst, orta ve alt kesimlerden ayrı ayrı ölçülmüştür. Gruplar uygunluğuna göre T testi ve Mann-Whitney $U$ testi ile karşılaştırılmıştır. Okuyucular arası uyum sınıf içi korelasyon katsayısı ile değerlendirildi.

Bulgular: Ortanca yaș [sırasıyla 55,5 (50-62) ve 55 (48,5-59,5) yıl, $p=0,48$ ] ve cinsiyet dağılımı [sırasıyla 18 (45\%) erkek ve 10 (58,8\%) kadın $p=0,34$ ] diyabetliler ve kontrol grubu için farklılık göstermemekteydi. Ortalama ve bağımsız 2B-SWH değerleri de benzerdi (Hepsi için p>0,05). Ortalama 2B-SWH değerleri albüminürisi olan ve olmayan grup için de benzerdi. Gözlemciler arası uyum iyiydi (ICC: 0.66 , 95\% CI: 0.19-0.88, $p=0.006$ ).

Sonuç: Böbrek elastisitesinin eGFR'si korunmuș, orta derecede albüminürisi olan ya da olmayan diyabetik hastalarda bozulmadığı görülmüştür.

Anahtar kelimeler: Shear wave elastografi, diyabet, albüminüri
Received: 26 June 2021

Accepted: 30 August 2021

Online First: 30 September 2021

Corresponding Author:

N. Gunduz

ORCID: 0000-0001-8754-5676

Istanbul Medeniyet University,

School of Medicine,

Department of Radiology, Istanbul, Turkey

gunduz.nesrin@gmail.com

A. Buz

ORCID: 0000-0003-1324-2810

A. Kabaalioglu

ORCID: 0000-0001-6247-1738

Istanbul Medeniyet University, School of Medicine,

Department of Radiology, Istanbul, Turkey 


\section{INTRODUCTION}

Chronic kidney disease (CKD) is defined as sustained kidney damage or a decrease in the estimated glomerular filtration rate (eGFR) less than $60 \mathrm{~mL} / \mathrm{min} / 1.73 \mathrm{~m}^{2}$ body surface area persisting for $\geq 3$ months ${ }^{1}$. Patients with eGFRs of $60-90 \mathrm{~mL} / \mathrm{min} / 1.73 \mathrm{~m}^{2}$ are considered to exhibit mild kidney dysfunction. Diabetes mellitus (DM) is one of the most common causes of kidney damage and dysfunction ${ }^{2}$. Type 2 DM (T2DM) triggers endothelial dysfunction and increases permeability to protein ${ }^{3}$. Moderate albuminuria, defined as a urinary albumin-to-creatinine ratio (uACR) of $30-300 \mathrm{mg} / \mathrm{g}$, is one of the most commonly used biomarkers of early renal injury.

The most common noninvasive imaging method employed to assess renal disease is ultrasonography (US) where renal size and cortical echogenicity and thickness serve as markers of $\mathrm{CKD}^{4,5}$. Although these conventional markers are correlated well with the eGFR and severity of albuminuria, they become apparent only relatively late in the disease course ${ }^{6}$. It is well-recognized that histological changes in kidneys commence prior to a measurable decline in the eGFR, thus before diagnostic US findings develop ${ }^{3}$. The typical histological changes in kidneys of T2DM patients include glomerular changes reflecting proteinuria ${ }^{7}$. Interstitial fibrosis develops during later stages and is associated with a decreased GFR, progressive deterioration of tissue elasticity, and increased renal stiffness ${ }^{3,6}$. Hence, a mildly decreased eGFR $\left(60-90 \mathrm{~mL} / \mathrm{min} / 1.73 \mathrm{~m}^{2}\right)$ or a combination of a moderately increased $\mathrm{UACR}$ and a preserved eGFR (>90 mL/min/1.73 $\mathrm{m}^{2}$ ) serve as surrogate markers of early kidney damage in patients with T2DM.

The so-called "gold standard" method used to detect early glomerular change is biopsy ${ }^{8}$, which is both invasive and inappropriate when prospective serial follow-up is required ${ }^{9}$. Moreover, the sensitivity of biopsy remains problematic, and sampling errors are possible ${ }^{8,10}$.
Hence, elastography methods, including magnetic resonance imaging ${ }^{11}$ and $\mathrm{US}^{6,9,12,13}$, have been increasingly used to assess kidney stiffness. Among the US shear wave elastography methods, two-dimensional shear wave velocity (2D-SWV) is a relatively novel technique that assesses tissue stiffness, yielding results comparable with those of transient elastography and point shear wave elastography ${ }^{14,15}$.

In one biopsy study, kidney elasticity was related to the CKD stage in a population without diabetes, but not in diabetics. Diabetes is a unique disease in which histological changes in the kidney do not necessarily resemble those of other CKD etiologies, particularly during early stages. Hence, we focused on T2DM patients with early kidney damage. Does such damage compromise renal elasticity? We enrolled T2DM patients and healthy controls and performed US-based 2DSWV measurements.

\section{MATERIAL and METHODS}

This prospective, observational single-center study was conducted in accordance with the Declaration of Helsinki and with the approval of our Institutional Research Ethics Committee. Written informed consents were obtained from all participants.

\section{Study design and participants}

Sample size calculation based on the mean SWV indicated that at least 14 T2DM patients and 14 healthy controls were required. However, as we planned to stratify the T2DM patients into two groups, we considered that 28 T2DM patients would be appropriate. The study was performed in our tertiary institution over three consecutive months. We enrolled 57 subjects including 40 outpatients with T2DM and 17 age- and sex-matched healthy controls. T2DM patients were recruited from our internal medicine and nephrology outpatient clinics and control subjects via in-hospital advertisements. 

Study

In the current study, early diabetic kidney damage was defined as either mildly decreased kidney function (eGFR=60-90 $\mathrm{mL} / \mathrm{min} / 1.73 \mathrm{~m}^{2}$ ) or moderately elevated albuminuria (uACR 30$300 \mathrm{mg} / \mathrm{g}$ ) against a background eGFR $\geq 90 \mathrm{~mL} /$ $\mathrm{min} / 1.73 \mathrm{~m}^{2}$. Patients with T2DM were divided into two subgroups according to the presence or absence of a moderately elevated uACR [Alb+ and Alb-subgroups]. During the initial screening of T2DM subjects, those who exhibited more than a mild reduction in the eGFR (i.e., $<60 \mathrm{~mL}$ / $\min / 1.73 \mathrm{~cm}^{2}$ ) or more than moderate proteinuria (urine ACR $>300 \mathrm{mg} / \mathrm{g}$ ), who were already being treated for proteinuria or had any other (confirmed) diabetic organ complication, any systemic disease that potentially involved the kidneys, any history or symptoms of cardiovascular disease, any common risk factors) for vascular disease (i.e., hypertension, smoking, or dyslipidemia) were excluded. The uACR was measured in earlymorning urine samples on at least two occasions and three months apart. The eGFR was calculated using the 2009 CKD-EPI formula based on serum creatinine values measured on at least two occasions and three months apart ${ }^{16}$.

No patient had been clinically scheduled for elastography; all were imaged for research purposes. We obtained conventional kidney US scans after the initial recruitment. Patients with abnormal findings (a renal tumor, hydronephrosis, a congenital anomaly, or any sign of acquired renal disease) and those with images of poor quality $(n=7)$ were excluded.

\section{US shear wave elastography}

The2D-SWV-basedUSelastographywasperformed using the Toshiba Aplio i800 ultrasound device fitted with an ultra-wideband convex transducer (model i8CX1) (Canon Medical Systems, Japan). All images were obtained from the patients in the lateral decubitus position (while holding their breath) by a skilled radiologist (N.G. with 12 years of experience in US imaging). The average depth during SWV assessment was $5.1 \mathrm{~cm}$. The sample box was placed in the renal cortices of the upper, middle, and lower portions of each kidney (Figure 1). A region-of-interest (ROI) of fixed size was chosen for each measurement. The 2D-SWV data were obtained four to six times for each renal region and the mean values were recorded. The mean 2D-SWV values of the entire right and left kidneys were calculated by averaging the means of the three renal regions. For assessment of interobserver reliability, a second radiologist (A.B. with 4 years of experience in US imaging) repeated the 2D-SWV measurements of the right kidneys in 10 randomly selected healthy subjects on the same day.

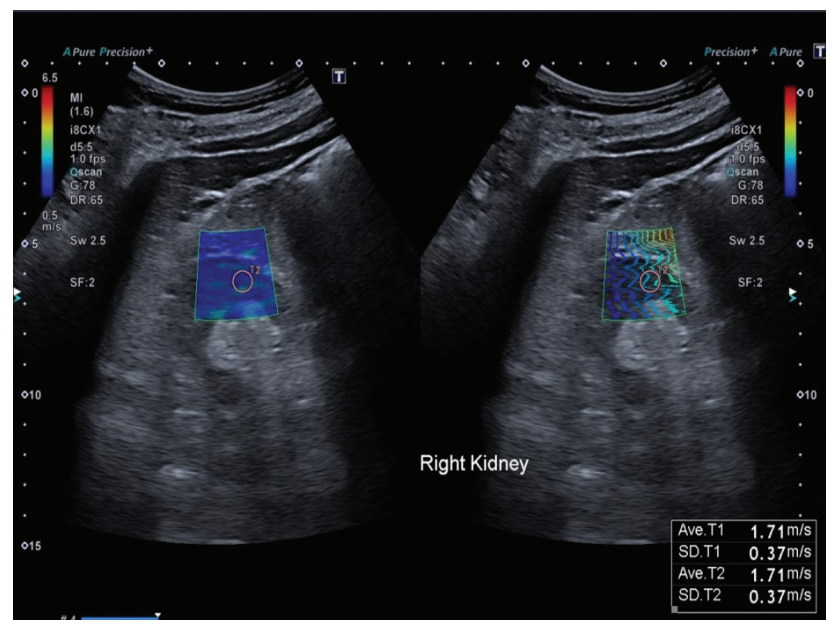

Figure 1. An example of shear wave velocity measurement. The box indicates the region of interest.

\section{Statistical analysis}

Statistical analysis was performed using SPSS ver. 19.0 (IBM SPSS Inc., Chicago, IL, USA). The normality of continuous variables was explored using the Shapiro-Wilk test. Descriptive statistics were reported as means with standard deviations for normally distributed continuous variables and as medians with $25^{\text {th }}$ and $75^{\text {th }}$ percentiles for others. Categorical variables were reported as frequencies with percentages. Independent twogroup comparisons of non-normally distributed continuous variables were performed using the Mann-Whitney U-test. The unpaired t-test was employed to compare normally distributed continuous variables. Proportions were compared 
between the groups using the Pearson chisquared test if the assumptions were valid. Otherwise, the Fisher exact test was employed. Given the accepted relationship between aging and loss of renal function, a logistic regression analysis model including age and the 2D-SWV measurements of certain kidney regions (with intergroup $p$-values $<0.05$ ) was used to predict Alb+status. The significance level was set to $p<0.05$ for all analyses.

A similar subgroup from a previous study was subjected to elasticity assessment ${ }^{17}$. Based on the mean SWVs in that study, we performed a priori sample size calculations for an alpha of 0.05, a beta of 0.20 , and an expected effect size of 0.20 (thus a 20\% lower SWVs were obtained in healthy individuals compared with diabetic subjects). The total required sample size was 28 ; however, we sought to enroll more than 14 patients in each group. Moreover, as we planned to stratify the T2DM patients into two subgroups, the sample size of the T2DM group was doubled.

\section{RESULTS}

We included 40 patients with T2DM and 17 age- and sex-matched healthy controls. There was no significant difference between the two groups in terms of the median age [55.5 (50-62) vs. 55 (48.5-59.5) years, $\mathrm{p}=0.48$ ] and sex ratio (M:F 22/18 vs. $7 / 10, p=0.34$ ). The inter-observer reliability of 2D-SWV analysis was good (intraclass correlation coefficient $=0.66,95 \% \mathrm{Cl} 0.19$ 0.88, $\mathrm{p}=0.006$ ).

Patients with T2DM were divided into two subgroups according to the UACR. Twentytwo T2DM (55\%) cases exhibited a moderately increased UACR and 18 (45\%) no albuminuria. The ages [55.5 (49.5-63) vs. 56 (51-60.25) years, $\mathrm{p}=0.71]$ and sex ratios $(M / F 11 / 11$ vs. $11 / 7$, $\mathrm{p}=0.48$ ) were similar between the Alb+ and Albsubgroups (Table 1).

\section{Comparison of the 2D-SWVs between the T2DM patients and healthy subjects}

There was no significant difference between the T2DM group and healthy controls in terms of the average 2D-SWV of the right [1.89 (1.73-2.18) vs. $1.99(1.83-2.38) \mathrm{m} / \mathrm{s}, \mathrm{p}=0.18$ ] and left [1.91 (1.662.13) vs. $1.95(1.58-2.1) \mathrm{m} / \mathrm{s}, \mathrm{p}=0.92]$ kidneys. The 2D-SWV values of the upper, middle, and lower kidney regions were similar between the groups (all p>0.05) for both kidneys (Table 2).

Comparison of the 2D-SWVs of the Alb+ vs. Alb- subgroups

There was no significant difference between the Alb+ and Alb- subgroups in terms of the average

Table 1. Demographic and Clinical Characteristics of the Study and Control Groups

\begin{tabular}{|c|c|c|c|}
\hline \multirow[b]{2}{*}{ Chracteristics } & \multicolumn{2}{|c|}{$\begin{array}{l}\text { Diabetic patients } \\
(\mathrm{n}=40)\end{array}$} & \multirow[b]{2}{*}{$\begin{array}{l}\text { Healthy controls } \\
(n=17)\end{array}$} \\
\hline & $\begin{array}{l}\text { Albuminuria (+) } \\
\mathbf{n}=\mathbf{2 2}\end{array}$ & $\begin{array}{l}\text { Albuminuria (-) } \\
n=18\end{array}$ & \\
\hline Age (years)* & $55.5(49.5-63)$ & $56(51-60.25)$ & 55 (48.5-59.5) \\
\hline \multicolumn{4}{|l|}{ Sex [n (\%)] } \\
\hline Female & $11(50)$ & $11(61.1)$ & $7(41.2)$ \\
\hline Duration of diabetes & $11(50)$ & $7(38.9)$ & $10(58.8)$ \\
\hline (years)* & $7(2.75-12)$ & $2.5(1.75-6.25)$ & - \\
\hline \multicolumn{4}{|l|}{ Drugs [n (\%)] } \\
\hline OAD & $7(31.8)$ & $13(72.2)$ & - \\
\hline OAD+Insulin & $15(68.2)$ & $5(27.8)$ & \\
\hline
\end{tabular}

Footnote: OAD: Oral antidiabetic

*Values are medians with quartiles 
N. Gunduz et al. Does Early Diabetic Kidney Damage Alter Renal Elasticity? An Ultrasound-Based, Two-Dimensional Shear Wave Elastography Study

Table 2. Comparison of SWV values between the T2DM group and healthy controls.

\begin{tabular}{llll}
\hline Measurement site & $\begin{array}{l}\text { T2DM group } \\
(\mathbf{n = 4 0 )}\end{array}$ & $\begin{array}{l}\text { Healthy controls } \\
(\mathbf{n = 1 7 )}\end{array}$ \\
\hline Right kidney $(\mathrm{m} / \mathrm{s})^{*}$ & & & P value $^{\dagger}$ \\
$\quad$ Average & $1.89(1.73-2.18)$ & $1.99(1.83-2.38)$ & 0.18 \\
$\quad$ Upper pole & $1.88(1.63-2.12)$ & $1.99(1.81-2.43)$ & 0.14 \\
$\quad$ Mid portion & $1.98(1.71-2.22)$ & $2.95(1.73-2.60)$ & 0.65 \\
$\quad$ Lower pole & $1.84(1.61-2.32)$ & $1.62-2.51)$ & 0.57 \\
Left kidney (m/s) & & & $0.92(1.58-2.10)$ \\
$\quad$ Average & $1.91(1.66-2.13)$ & $1.82(1.70-2.14)$ & 0.29 \\
$\quad$ Upper pole & $1.83(1.55-2.03)$ & $1.85(1.42-2.32)$ & 0.56 \\
$\quad$ Mid portion & $1.82(1.46-2.20)$ & $1.89(1.57-2.08)$ \\
$\quad 1.84(1.62-2.25)$ & & 0.51 \\
\hline
\end{tabular}

Footnote: SWV: Shear wave velocity, T2DM: Type 2 Diabetes Mellitus

* The values are medians along with $25^{\text {th }}$ and $75^{\text {th }}$ percentiles within parentheses

+ Calculated using Mann-Whitney-U test since the distributions of data were not normal

Table 3. Comparison of SWV values between the Alb+ and Alb- subgroups.

\begin{tabular}{llll}
\hline Measurement site & Alb+ $(\mathbf{n}=\mathbf{2 2})$ & Alb- $(\mathbf{n}=\mathbf{1 8})$ & P value \\
\hline Right kidney $(\mathrm{m} / \mathrm{s})^{*}$ & & & \\
$\quad$ Average & $2.00(1.75-2.28)$ & $1.83(1.71-2.06)$ & $0.32^{\dagger}$ \\
Upper pole & $2.04(1.68-2.40)$ & $1.82(1.50-2.05)$ & $0.04^{\S}$ \\
Mid portion & $1.98(1.58-2.21)$ & $2.05(1.77-2.24)$ & $0.94^{\dagger}$ \\
Lower pole & $1.84(1.61-2.32)$ & $1.76(1.55-2.10)$ & $0.37^{\dagger}$ \\
Left kidney (m/s) & & $1.83(1.63-2.11)$ & $0.13^{\dagger}$ \\
Average & $1.99(1.69-2.24)$ & $1.54(1.35-2.00)$ & $0.35^{\S}$ \\
Upper pole & $2.02(1.46-2.43)$ & $1.77(1.50-1.98)$ & $0.03^{\dagger}$ \\
Mid portion & $1.96(1.64-2.23)$ & & $0.11^{\dagger}$ \\
Lower pole & $1.96(1.70-2.34)$ & & \\
\hline
\end{tabular}

Footnote: SWV: Shear wave velocity, Alb: Albuminuria

* The values are medians along with $25^{\text {th }}$ and $75^{\text {th }}$ percentiles within parantheses

+ Calculated using Mann-Whitney-U test since the distributions of data were not normal

${ }^{\S}$ Calculated using unpaired $T$ test since the data distributions were normal

2D-SWVs of the right [2 (1.75-2.28) vs. 1.83 $(1.71-2.06) \mathrm{m} / \mathrm{s}, \mathrm{p}=0.32]$ and left [1.99 (1.69$2.24)$ vs. 1.76 (1.55-2.1), $p=0.13$ ] kidneys. Only the 2D-SWV values of the upper poles of the right kidneys $[2.02(1.46-2.43)$ vs. 1.83 (1.632.11) $\mathrm{m} / \mathrm{s}, \mathrm{p}=0.04]$ and the middle regions of the left kidneys $[1.96(1.64-2.23)$ vs. $1.54(1.35-2)$ $\mathrm{m} / \mathrm{s}, \mathrm{p}=0.03$ ] were significantly higher in the Alb+ subgroup. The 2D-SWVs of the remaining regions of both kidneys did not differ between the subgroups (Table 3 ).

\section{Effect of sex on the 2D-SWVs}

All 2D-SWVs of individual kidney regions and the average 2D-SWVs of both kidneys were similar for both males and females (all $\mathrm{p}>0.05$ ).

\section{Effect of age on 2D-SWV}

A weak positive correlation was evident between age and the average 2D-SWVs of the left kidneys (correlation coefficient 0.29, $\mathrm{p}=0.03$ ). However, no such correlation was evident for the right kidneys (correlation coefficient 0.054, $\mathrm{p}=0.69$ ).

\section{Prediction of albuminuria}

As 2D-SWVs of the right kidney upper pole and the left kidney middle region portion seemed to differ significantly between the Alb+ and Albsubgroups, and as age exhibited some correlation with the SWV, logistic regression analysis was performed. The first model included age and the left middle region SWV which were not significant predictors of albuminuria. The second model 
included age and the right upper pole SWV; again, the results were negative (Table 4).

Table 4. Age adjustment for both LMP and RUP elasticities for predicting Alb+ status.

\begin{tabular}{llllll}
\hline & & \multicolumn{3}{c}{$95 \%$ Confidence interval } \\
\cline { 5 - 5 } Model & Wald & OR & Lower limit Upper limit & P value \\
\hline Age & 1.33 & 1.05 & 0.97 & 1.13 & 0.25 \\
LMP-SWV & 3.62 & 4.43 & 0.96 & 20.55 & 0.06 \\
Age & 0.33 & 1.02 & 0.95 & 1.09 & 0.56 \\
RUP-SWV & 3.33 & 4.68 & 0.89 & 24.56 & 0.68
\end{tabular}

Footnote: SWV: Shear wave velocity, Alb: Albuminuria

* The values are medians along with $25^{\text {th }}$ and $75^{\text {th }}$ percentiles within parantheses

${ }^{+}$Calculated using Mann-Whitney-U test since the distributions of data were not normal

${ }^{\S}$ Calculated using unpaired $T$ test since the data distributions were normal

\section{DISCUSSION}

Our principal finding from this study was that US-based 2D-SWV measurements do not reveal early kidney damage caused by diabetes. Kidney elasticity did not differ between the T2DM patients and healthy subjects or between T2DM patients with and without albuminuria. T2DM triggers microstructural changes in the renal parenchyma prior to a significant decrease in the eGFR ${ }^{3}$. A moderately increased $u A C R$ is indicative of kidney damage and is associated with future risk of progression to kidney dysfunction and cardiovascular complications (independent of the eGFR $)^{16}$. We accept that histological changes may be apparent in some T2DM patients before pathological levels of urinary albumin are detectable ${ }^{3,7}$. Hence, it might be argued that biopsy is required for definitive confirmation of the typical diabetic changes in glomeruli ${ }^{8}$. However, biopsy is not a routine procedure for all T2DM cases, being usually reserved for those with certain relevant indications ${ }^{9}$. None of our study subjects exhibited either a routine or compelling indication for biopsy because the cause of early kidney damage was not controversial. In the landmark study of Fioretto et al., microalbuminuric T2DM patients with normal eGFRs underwent kidney biopsy for research purposes rather than clinical indications ${ }^{18}$. The cited authors found histopathological changes (either typical glomerular or atypical tubulointerstitial and vascular changes) in 70\% of T2DM subjects. This work established that an eGFR of $60-90 \mathrm{~mL} /$ $\mathrm{min} / 1.73 \mathrm{~m}^{2}$ or a moderately elevated UACR in the context of a preserved eGFR reflects earlystage diabetic renal injury. We used these criteria in our current study. Again, biopsies were not performed.

Conventional kidney US alone usually cannot permit early recognition of kidney damage. Indeed, the typical US findings of CKD reflect irreversible late changes ${ }^{4-6}$. Moreover, the conventional US CKD findings are not specific for diabetic nephropathy, because diseases of diverse etiologies share such imaging changes. However, elastography assesses increased tissue stiffness caused by damage to the liver, breasts, thyroid, prostate, and kidneys 9 . We used (relatively) novel US shear wave elastography method to assess kidney stiffness. 2D-SWV measurements yield results comparable with those of conventional transient elastography and acoustic radiation force imaging when evaluating liver fibrosis ${ }^{15}$. Although the SWVs were correlated positively with the extent of liver fibrosis ${ }^{19}$, they were correlated negatively with the CKD stage and eGFR $^{6,12}$. The mechanism underlying the inverse relationship between kidney stiffness and the eGFR in CKD patients remains unclear. Changes in renal perfusion were suggested to affect measurements of stiffness ${ }^{20}$. Acoustic radiation force impulse (ARFI)-derived SWVs were higher in T2DM patients than the healthy controls ${ }^{21}$. Another study reported increased SWVs in patients with T2DM-induced early kidney damage, but not in those with non-diabetic CKD (i.e., eGFR >60 mL/ 
min/1.73 $\mathrm{m}^{2}$ ), unlike patients with diabetic CKD (i.e., eGFR $\left.<60 \mathrm{~mL} / \mathrm{min} / 1.73 \mathrm{~m}^{2}\right)^{22}$. Our results do not support these findings. The whole-kidney average SWVs did not increase either in T2DM patients (compared with healthy controls) or in Alb+ or Alb- subjects. This apparent contradiction can be explained by differences in the study populations. Goya et al. ${ }^{17}$ did not exclude patients with comorbidities (hypertension, systemic diseases, other diabetic organ complications, and risk factors for vascular diseases) that may affect the elasticity results. We carefully selected our subjects; any confounder of elasticity is likely absent. In addition, the sonographic technique used for elasticity assessment may affect the results. We derived 2D-SWVs, whereas the cited authors used the ARFI method.

On univariate analysis, the elasticities of the left middle and right upper kidney regions seemed to be selectively disturbed in the Alb+ cases. This could be attributable to the potentially asynchronous severity of changes in different kidney regions ${ }^{8,10}$. Indeed, heterogeneous renal histopathological changes were reported in albuminuric patients with $\mathrm{T}_{2} \mathrm{DM}^{23,24}$. However, the SWVs did not predict Alb+ status on multivariate analysis after adjustment for age. Hence, any focal elasticity impairment in the Alb+ group, compared with the Alb- group, is unlikely.

Our results suggest that early diabetic histological kidney changes do not compromise elasticity, or that any such change cannot be revealed by US-based 2D-SWV. Impairment of wholekidney elasticity probably requires the profound histological changes of diabetic nephropathy. Previous studies reported reduced global kidney SWV and eGFR values in both patients with and those without severe proteinuria ${ }^{6,12,19}$. However, such findings probably require kidney damage that is more severe than glomerulosclerosis, such as irreversible tubulointerstitial fibrosis and vascular changes. We believe that 2D-SWV measurements have not yet revealed early compromised kidney elasticity (a surrogate marker of early kidney damage). However, as our results conflict with those of a previous work that used the ARFI technique, further well-controlled longitudinal studies in larger patient series, using biopsy and histopathology as the reference standards, are required. Limited acoustic wave penetration in obese patients and motion artifacts caused by breathing movements reduce the validity and reliability of $\mathrm{SWE}^{25}$.

Repeat assessments by the second radiologist could be performed in 10 cases which we considered sufficient for reproducibility assessment. The reproducibility of 2D-SWV was good, and the intra-class correlation coefficient of inter-observer agreement was 0.66 , close to that of the previous reports.

The major strength of our study is that we are the first to evaluate the ability of novel 2D-SWV US elastography to detect early kidney damage in patients with T2DM. Furthermore, we applied strict inclusion criteria to eliminate potential confounders (disturbed elasticity and proteinuria). The sample size was calculated a priori, and the number of patients was adequate to reveal differences in the SWVs between the study groups.

The main limitation of our study is that kidney damage was not confirmed histopathologically. We believe that a mildly decreased eGFR or a combination of moderate albuminuria and a preserved eGFR will reveal early diabetic kidney damage when biopsy is not possible. Although very unlikely, other causes of a moderately increased $u A C R$ or mildly reduced eGFR cannot be entirely excluded based on anamnesis and symptoms alone. In conclusion, kidney elasticity does not seem to be compromised in patients with diabetes and preserved eGFR, with or without moderate albuminuria. 


\section{REFERENCES}

1. Kidney Disease: Improving Global Outcomes (KDIGO) CKD Work Group. KDIGO 2012 clinical practice guideline for the evaluation and management of chronic kidney disease. Kidney Int Suppl. 2013;3:1-150.

2. Webster AC, Nagler EV, Morton RL, Masson P. Chronic kidney disease. Lancet. 2017;389: 1238-52. [CrossRef]

3. Schena FP, Gesualdo L. Pathogenetic mechanisms of diabetic nephropathy. J Am Soc Nephrol. 2005; 16:S30-3. [CrossRef]

4. Yamashita SR, von Atzingen AC, lared W, et al. Value of renal cortical thickness as a predictor of renal function impairment in chronic renal disease patients. Radiol Bras. 2005;48:12-6. [CrossRef]

5. Beland MD, Walle NL, Machan JT, Cronan JJ. Renal cortical thickness measured at ultrasound: is it better than renal length as an indicator of renal function in chronic kidney disease? AJR Am J Roentgenol. 2010;195:W146-9. [CrossRef]

6. Lin HY, Lee YL, Lin KD, et al. Association of renal elasticity and renal function progression in patients with chronic kidney disease evaluated by real-time ultrasound elastography. Sci Rep. 2017;7:43303. [CrossRef]

7. White KE, Bilous RW. Type 2 diabetic patients with nephropathy show structural-functional relationships that are similar to type 1 disease. J Am Soc Nephrol. 2000;11:1667-73. [CrossRef]

8. Walker PD, Cavallo T, Bonsib SM; Ad Hoc Committee on Renal Biopsy Guidelines of the Renal Pathology Society. Practice guidelines for the renal biopsy. Mod Pathol. 2004; 17:1555-63. [CrossRef]

9. Sigrist RMS, Liau J, Kaffas AE, Chammas MC, Willmann JK. Ultrasound elastography: review of techniques and clinical applications. Theranostics. 2017;7:1303-29. [CrossRef]

10. Cunningham A, Benediktsson H, Muruve DA, Hildebrand AM, Ravani P. Trends in biopsy-based diagnosis of kidney disease: a population study. Can J Kidney Health Dis. 2018;5:2054358118799690. [CrossRef]

11. Li J, An C, Kang L, Mitch WE, Wang Y. Recent advances in magnetic resonance imaging assessment of renal fibrosis. Adv Chronic Kidney Dis. 2017;24:150-3. [CrossRef]

12. Guo LH, Xu HX, Fu HJ, Peng A, Zhang YF, Liu LN. Acoustic radiation force impulse imaging for noninvasive evaluation of renal parenchyma elasticity: preliminary findings. PLoS One. 2013;8:e68925. [CrossRef]
13. Singh H, Panta OB, Khanal U, Ghimire RK. Renal cortical elastography: normal values and variations. J Med Ultrasound. 2017;25:215-20. [CrossRef]

14. Lee ES, Lee JB, Park HR, et al. Shear wave liver elastography with a propagation map: diagnostic performance and inter-observer correlation for hepatic fibrosis in chronic hepatitis. Ultrasound Med Biol. 2017;43:1355-63. [CrossRef]

15. Ferraioli G, De Silvestri A, Lissandrin R, et al. Evaluation of inter-system variability in liver stiffness measurements. Ultraschall Med. 2019;40:64-75. [CrossRef]

16. Levey AS, de Jong PE, Coresh J, et al. The definition, classification, and prognosis of chronic kidney disease: a KDIGO Controversies Conference report. Kidney Int. 2011;80:17-28. [CrossRef]

17. Goya C, Kilinc F, Hamidi C, et al. Acoustic radiation force impulse imaging for evaluation of renal parenchyma elasticity in diabetic nephropathy. AJR Am J Roentgenol. 2015;204:324-9. [CrossRef]

18. Fioretto $P$, Mauer M, Brocco E, et al. Patterns of renal injury in NIDDM patients with microalbuminuria. Diabetologia. 1996;39:1569-76. [CrossRef]

19. Yang H, Sun Y, Tang Y, Lu Y, Hu B, Ying T. Shear-wave elastography of the liver in a healthy pediatric population. J Clin Ultrasound. 2020;48:139-44. [CrossRef]

20. Asano K, Ogata A, Tanaka K, et al. Acoustic radiation force impulse elastography of the kidneys: is shear wave velocity affected by tissue fibrosis or renal blood flow? J Ultrasound Med. 2014;33:793-801. [CrossRef]

21. Bob F, Grosu I, Sporea I, et al. Ultrasound-based shear wave elastography in the assessment of patients with diabetic kidney disease. Ultrasound Med Biol. 2017;43:2159216. [CrossRef]

22. Reidy K, Kang HM, Hostetter T, Susztak K. Molecular mechanisms of diabetic kidney disease. J Clin Invest. 2014;124:2333-40. [CrossRef]

23. Ekinci EI, Jerums G, Skene A, et al. Renal structure in normoalbuminuric and albuminuric patients with type 2 diabetes and impaired renal function. Diabetes Care. 2013;36:3620-6. [CrossRef]

24. Fioretto $P$, Mauer $M$. Diabetic nephropathy: diabetic nephropathy-challenges in pathologic classification. Nat Rev Nephrol. 2010;6:508-10. [CrossRef]

25. Bruce M, Kolokythas O, Ferraioli G, Filice C, O’Donnell $M$. Limitations and artifacts in shear-wave elastography of the liver. Biomed Eng Lett. 2017;7:81-9. [CrossRef] 